\title{
Diversity and vertical distribution of psocids (Psocodea: Psocoptera) in two forests of the Colombian Amazon
}

\author{
Jeferson Panche-Chocué ${ }^{1}$, Ranulfo González-Obando ${ }^{1 *} \&$ Alfonso N. García Aldrete ${ }^{2}$ \\ 1. Grupo de Investigaciones Entomológicas, Departamento de Biología, Facultad de Ciencias Naturales y Exactas, \\ Universidad del Valle, Santiago de Cali, Colombia; jefersonpanche@gmail.com, \\ ranulfo.gonzalez@correounivalle.edu.co \\ 2. Departamento de Zoología, Instituto de Biología, Universidad Nacional Autónoma de México, Apdo. Postal 70-153, \\ CdMx, México; anga@ib.unam.mx \\ * Correspondence
}

Received 04-IX-2019. Corrected 01-V-2020. Accepted 22-VI-2020.

\begin{abstract}
Introduction: The knowledge on the diversity of psocids in Colombia has increased, following the global trend, but the main interest of most of the studies has been oriented to solve taxonomic aspects, leaving aside other biological aspects, of which little is known, such as the ecological interactions of these organisms in tropical forests. Objective: To describe the psocid diversity in two Colombian Amazonian localities and provide the first data on their vertical distribution in tropical forests. Methods: Monthly samplings of Psocoptera were conducted during new moon periods, from July 2014 to May 2015. Surveys were carried out in two localities of the Putumayo department, Colombia (Puerto Asís and Mocoa), using LED light traps. Results: During the sampling period, 152 species, in 23 genera and nine families were collected. The richest family was Psocidae, followed by Epipsocidae and Lachesillidae. More than $80 \%$ of the species found are still undescribed, and among the described ones, nine represent new records for Colombia, and are shared with neighboring countries in the Amazon basin. Fourteen (9.2\%) species are shared by the two localities surveyed. Puerto Asís is considerably richer than Mocoa. Vertical stratification of Psocoptera was found in both localities, with the canopy being the most species rich stratum. Conclusion: The relatively high diversity of psocidos found, as well as the high number of new species, is an indicator of the need to continue the exploration of these organisms in the rest of the Colombian territory and Andean countries, especially in the Amazon foothills. Stratification of the studied psocoptera community was evident, with the canopy stratum being the richest in species, a trend that continues throughout the year.
\end{abstract}

Key words: canopy; understory; ecology; stratification; Putumayo.

Panche-Chocué, J., González-Obando, R., \& García Aldrete, A.N. (2020). Diversity and vertical distribution of psocids (Psocodea: Psocoptera) in two forests of the Colombian Amazon. Revista de Biología Tropical, 68(3), 898-908.

Psocids (book lice or bark lice) (Insecta: Psocodea:'Psocoptera'), presently include 5 941 species in 485 genera, according to the literature through 2014 (Mockford, 2018). This number has increased significantly in recent years, as a result of the efforts of various research groups in the neotropics. The number of species recorded in Colombia through the year 2000 (Lienhard \& Smithers, 2002), was 78 , in 42 genera and 20 families. Presently, the number of Colombian species has reached 720 , a large percentage of which remain undescribed (García Aldrete, Carrejo, Mendivil, Calderón, Saenz, et al., 2018). Colombia is thus one of the countries most diverse for psocids, in accordance with its megadiverse nature. 
Due to their spatial complexity, the forests of the Amazon Basin have a large number of microhabitats available along the canopyunderstory gradient, resulting in an increase of specialization and diversity of the organisms that live there (Davis, Sutton, \& Brendell, 2011). For instance, as Turner (1975) pointed out, the contribution of macroepiphytes to the primary production in these forests is significant, and due to the close relationship suggested between psocids and macroepiphytes, these forests could have a high alpha diversity of psocids.

This work, besides contributing to the knowledge of neotropical psocid diversity, also provides the first data on their vertical distribution in tropical forests, which, besides allowing to make inferences on some ecological interactions, will also allow researchers to decide where to focus the sampling effort to get better results, when sampling areas with similar characteristics.

\section{MATERIALS AND METHODS}

Study site: The samplings were conducted in two localities, in the municipalities of Mocoa and Puerto Asís, Department of Putumayo, Colombia (Fig. 1). The first locality is located at $\left(1^{\circ} 06^{\prime} 34.50^{\prime \prime} \mathrm{N} \& 76^{\circ} 36^{\prime} 41.52^{\prime \prime} \mathrm{W}\right)$, at 902 m.a.s.l. and $8 \mathrm{~km}$ from the urban area of Mocoa, in the trail San José del Pepino, in the area known as "Fin del mundo", buffer area of the Serranía de los Churumbelos National Natural Park, in the Amazonian piedmont. Despite its proximity to the agricultural frontier, this area has $90 \%$ of primary forest, with a mean canopy height of $20 \mathrm{~m}$. The remaining $10 \%$ of land includes pastures, abandoned coffee plantations, and roads. The area has many streams affluent of the Dantayaco river.

The second locality is in the municipality of Puerto Asís, at $15 \mathrm{Km}$ on the road Puerto Asís-Teteyé, with an average altitude of 260 m.a.s.l., at $0^{\circ} 23^{\prime} 21.01^{\prime \prime} \mathrm{N} \& 76^{\circ} 31^{\prime} 41.87^{\prime \prime} \mathrm{W}$.

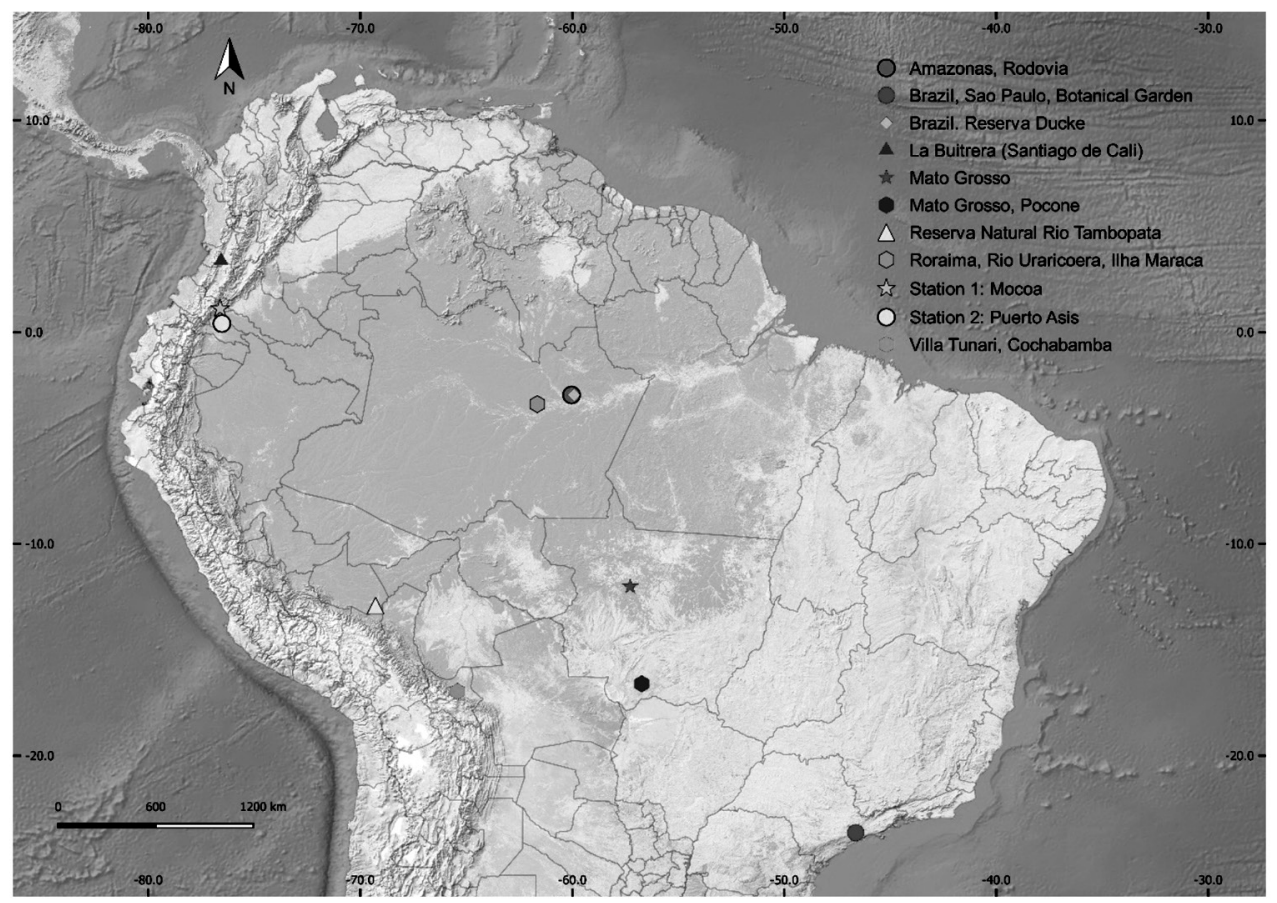

Fig. 1. Localities with previous records of species of psocids and present study in two localities of the Putumayo department, Colombia. In blue star (Station 1: Mocoa), in yellow circle (Station 2: Puerto Asis), samplings carried out between July 2014 and May 2015. 
This area is primarily agricultural, with many extensive forest fragments, trees of an average height of $15 \mathrm{~m}$, in a matrix of small rice fields (Oryza sativa L.), banana plantations (Musa paradisiaca L.), and large pasture lands. Despite their differences in average temperature, precipitation and altitude, both localities are classified as tropical humid forests (Bh-t), according to the map of continental, coastal and marine ecosystems of Colombia (Instituto de Hidrología, Meteorología y Estudios Ambientales, IDEAM, 2007). The two localities are $90 \mathrm{~km}$ apart.

\section{Collection and taxonomic identification:}

The specimens were captured utilizing LED light traps, between 18:00 h and 06:00 h., during 3 days, in the periods of new moon, from July 2014 to May 2015. The specimens were placed in vials with $80 \%$ ethanol and were taken to the laboratory of the Group of Entomological Investigations, Universidad del Valle, Santiago de Cali, to be identified to family, genus, and species, when possible. Specimens of unambiguously identified morphs were dissected in $80 \%$ ethanol, and their parts (head, right legs and wings, and genitals), were mounted in Canada balsam, following standard procedures. For the identification, the pertinent available literature was utilized (New \& Thornton, 1975; New, 1980; Thornton, 1981; Smithers, 1990; García Aldrete, 1996, 1998, 2000, 2005, 2010; García Aldrete, González, Carrejo, Mendivil \& Calderón, 2013; González, Saldaña \& García Aldrete, 2013; Silva Neto, Rafael \& García Aldrete, 2014). The specimens are deposited in the Entomological Museum, Universidad del Valle (MUSENUV), Santiago de Cali, Colombia.

Psocid diversity: With the data obtained, species accumulation curves were constructed, to evaluate the representativity of the sampling in each locality, as well as for the strata sampled; the non-parametric estimator CHAO 1 was used, utilizing EstimateS software 9.1.0 for Windows (Colwell, 2013). With the data of richness and abundance, the effective number of species was calculated for each locality (Jost, 2006), using it as a descriptor of diversity. From the values obtained, a graphic description was made, to represent the fluctuation of the diversity in each locality during the sampling period. Due to the differences in sampling effort in the two localities and to compare their diversity values, the rarefaction method was utilized (Gotelli \& Colwell, 2011), using the package Vegan (Oksanen, Guillaume-Blanchet, Kindt, Legendre, Minchin, et al., 2013) available in the free software R (2013).

Vertical distribution of psocids (understory-canopy): The vertical distribution of the psocid community was evaluated with the data from the months of August 2014, and January and May 2015 for Mocoa, and July and October 2014, and January and February 2015 for Puerto Asís. During these months the LED traps were placed in $200 \mathrm{~m}$ transects, with 4 points by transect and 2 traps, one at one meter above ground (understory) and the other at 10 meters above ground (canopy), in each point. Due to the impossibility to associate the females with their respective males, we only worked with the males collected. The differences in the species composition in the two strata were corroborated by means of an analysis of variance not parametric Kruskal-Wallis, using the statistic software PAST version 3.08 (Hammer, Harper \& Ryan, 2015).

\section{RESULTS}

Diversity and composition of the psocid community: During the sampling period, 421 specimens were collected and 9 families, 27 genera and 152 species were identified. The records of Perucania longiareola New \& Thornton, Euplocania badonneli New \& Thornton, Terryerwinia acutiphallica García Aldrete, Nadleria ca. mariateresae García Aldrete, and Lachesilla pigmentipenna García Aldrete are remarkable, as these species had only been recorded in the Tambopata Reserved Zone, in Madre de Dios, Peru (New \& Thornton, 1988; García Aldrete, 1996, 2005, 2008). 
Similarly Triplocania lamasi Silva Neto et al. and Lachesilla bicornata New \& Thornton, recorded for Mato Grosso, Brazil (New \& Thornton, 1975; Silva Neto et al., 2014), Amazolachesilla sp., of a genus only known in the state of Amazonas, Brazil (García Aldrete \& Mockford, 2011), Dolabellopsocus similis Mockford, previously recorded in Roraima, Brazil and Valle del Cauca, Colombia (Calderón-Martínez, González-Obando, \& García Aldrete, 2014), besides Cladiopsocus ramulosus (Enderlein) from Peru (Fig. 1).

Psocidae was the most abundant family, with 34 species ( $31.6 \%$ of the total), followed by Epipsocidae with 28 species $(18.4 \%$ of the total), Ptiloneuridae with 24 species (16 $\%$ of the total), Lachesillidae with 21 species (14\% of the total), and Dolabellopsocidae with 10 species $(6.6 \%$ of the total). The other families, Myopsocidae, Cladiopsocidae, Peripsocidae and Philotarsidae, constituted the other $13.9 \%$. About $80 \%$ of the species in the families Ptiloneuridae, Epipsocidae, Myopsocidae, Dolabellopsocidae and Cladiopsocidae are probably undescribed.

For the locality of Puerto Asís, 115 especies, in 23 genera and nine families were recorded. Psocidae was the most abundant family ( 33 species and $23.5 \%$ of the total abundance), followed by Epipsocidae, with 30 species, Lachesillidae (19 species), Ptiloneuridae (13 species) and Dolabellopsocidae (6 species). The families Cladiopsocidae, Myopsocidae, Philotarsidae and Peripsocidae represented the remaining $29 \%$. The index of equity for this locality was 0.76 (Table 1). The genera Perucania, Loneura, Thyrsopsocus, Steleops, Psococerastis, Amazolachesilla, Hemicaecilius and Neurostigma were exclusive to this locality.

For the locality of Mocoa, 53 species, in 15 genera and nine families were recorded. The index of equity for this locality was smaller than that of Puerto Asís (0.71). Cladiopsocidae was the most abundant family (27.4\% of the total of specimens collected), although with only four species recorded, followed by Psocidae, with $26 \%$ of the total abundance (20 species), Peripsocidae, with $9.6 \%$ of the total abundance (3 species), Epipsocidae (9 species), and Philotarsidae (2 species), both with $8.2 \%$ of the total abundance. The other families had each a representation of less than $4 \%$ of the total abundance. Of the total species richness, 14 species were shared by the two localities (Table 2).

The sampling effort for Mocoa was 132 hours/trap, and for Puerto Asís it was 198 hours/trap; considering that in each locality eight traps were set up, there were 1056 effective hours of sampling in Mocoa, and 1584 effective hours of sampling in Puerto Asís. Species accumulation curves for each locality showed that more sampling effort was needed to achieve a high representativity of the community (Fig. 2). The rarefaction curve, with the data of the two localities (Fig. 3) shows that, if the sampling effort had been the same for the two localities, Puerto Asís would have had higher diversity values.

TABLE 1

Measurements of diversity of order $q$, calculated for the samples collected in each of the stratum of each locality

\begin{tabular}{rlcccc}
$r$ & & $q=0$ (Species richness) & $q=1$ & $q=2$ & $q=2 / q=1$ (Equity index) \\
\multirow{2}{*}{ Puerto Asís } & Total & 124 & 90.12 & 68.73 & 0.76 \\
& Canopy & 90 & 68.29 & 52.94 & 0.77 \\
\multirow{3}{*}{ Mocoa } & Understory & 22 & 20.75 & 19.56 & 0.94 \\
& Total & 53 & 39.13 & 27.81 & 0.71 \\
& Canopy & 40 & 29.99 & 21.23 & 0.71 \\
& Understory & 9 & 7.56 & 6 & 0.79 \\
\hline
\end{tabular}

$q=0$, weighted harmonic mean; $q=1$, weighted geometric mean; $q=2$, weighted arithmetic mean. 
TABLE 2

Genera of Psocoptera in two localities of the Colombian Amazonia collected with lightraps

\begin{tabular}{|c|c|c|c|c|c|c|c|}
\hline \multirow[b]{2}{*}{ Family } & \multirow[b]{2}{*}{ Genus } & \multicolumn{3}{|c|}{ Mocoa } & \multicolumn{3}{|c|}{ Puerto Asís } \\
\hline & & $\begin{array}{l}\text { Number of } \\
\text { species }\end{array}$ & $\begin{array}{c}\text { Abundance } \\
\text { Canopy }\end{array}$ & $\begin{array}{l}\text { Abundance } \\
\text { Understory }\end{array}$ & $\begin{array}{l}\text { Number of } \\
\text { species }\end{array}$ & $\begin{array}{l}\text { Abundance } \\
\text { Canopy }\end{array}$ & $\begin{array}{l}\text { Abundance } \\
\text { Understory }\end{array}$ \\
\hline Cladiopsocidae & Cladiopsocus & 4 & 20 & 1 & 3 & 4 & 0 \\
\hline \multirow[t]{2}{*}{ Dolabellopsocidae } & Dolabellopsocus & 3 & 3 & 0 & 3 & 18 & 3 \\
\hline & Isthmopsocus & 1 & 1 & 0 & 3 & 8 & 2 \\
\hline \multirow[t]{4}{*}{ Epipsocidae } & Epipsocus & 4 & 6 & 0 & 17 & 47 & 8 \\
\hline & Gojaoides & 1 & 1 & 0 & 1 & 4 & 0 \\
\hline & Neurostigma & 0 & 0 & 0 & 1 & 2 & 0 \\
\hline & Terryerwinia* & 1 & 1 & 0 & 1 & 7 & 0 \\
\hline \multirow[t]{2}{*}{ Lachesillidae } & Lachesilla & 1 & 2 & 0 & 13 & 39 & 8 \\
\hline & Nadleria* & 0 & 0 & 0 & 1 & 3 & 0 \\
\hline Myopsocidae & Myopsocus & 1 & 2 & 0 & 2 & 5 & 0 \\
\hline Peripsocidae & Peripsocus & 3 & 7 & 5 & 4 & 8 & 0 \\
\hline Phillotarsidae & Aaroniella & 2 & 6 & 2 & 1 & 1 & 0 \\
\hline \multirow[t]{6}{*}{ Psocidae } & Psocidae & 13 & 16 & 3 & 18 & 39 & 6 \\
\hline & Psococerastis & 0 & 0 & 0 & 1 & 3 & 0 \\
\hline & Psocus & 0 & 0 & 0 & 1 & 10 & 0 \\
\hline & Steleops & 0 & 0 & 0 & 3 & 3 & 0 \\
\hline & Thyrsopsocus & 0 & 0 & 0 & 1 & 1 & 0 \\
\hline & Trichadenoctenum & 3 & 3 & 0 & 3 & 7 & 0 \\
\hline \multirow[t]{4}{*}{ Ptiloneuridae } & Euplocania & 1 & 2 & 0 & 4 & 9 & 0 \\
\hline & Loneura & 0 & 0 & 0 & 1 & 4 & 0 \\
\hline & Perucania* & 0 & 0 & 0 & 1 & 1 & 0 \\
\hline & Triplocania & 3 & 3 & 1 & 7 & 15 & 2 \\
\hline
\end{tabular}

The genera with * represent new records for Colombia.
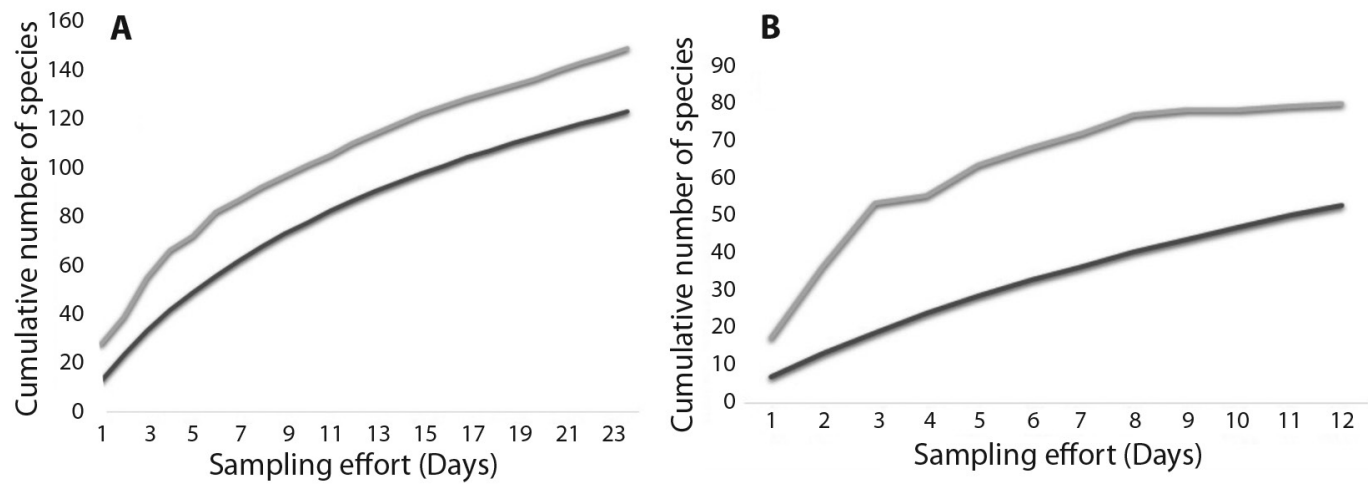

Fig. 2. Psocid species accumulation curves in two localities of the Putumayo department, Colombia. A. Puerto Asis. B. Mocoa. In black observed richness, in gray Chao 1 estimator. In Puerto Asis, $82.6 \%$ of the expected diversity was surveyed while in Mocoa only $66.3 \%$ was reached. 


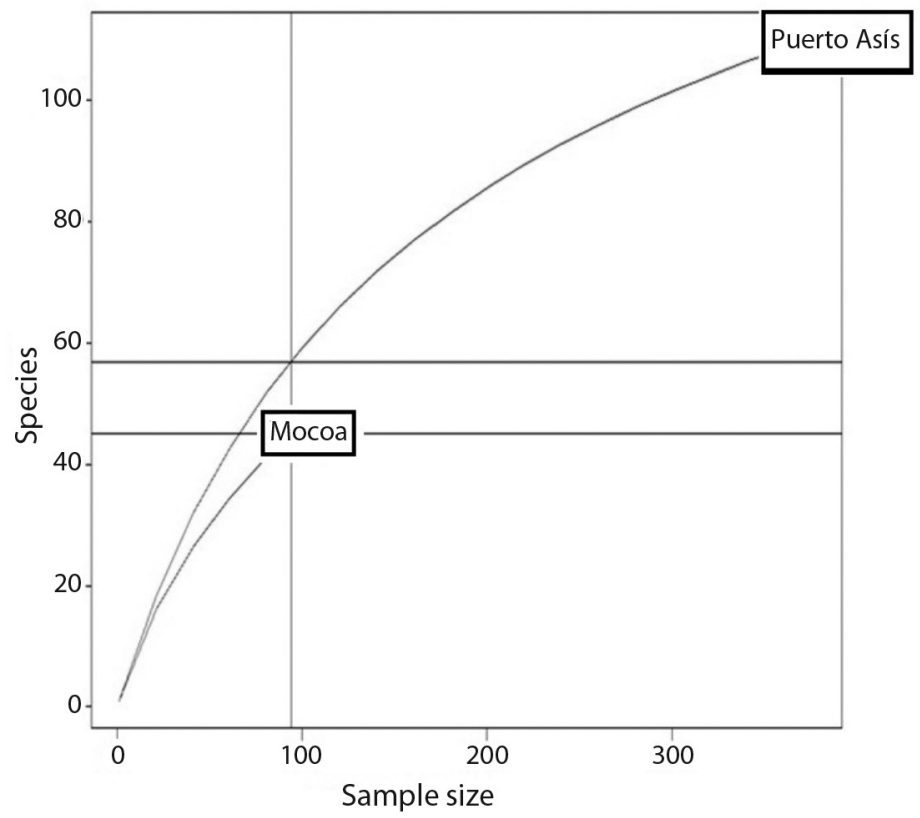

Fig. 3. Species rarefaction curves comparing local diversity of psocids in natural areas of Puerto Asis and Mocoa (Putumayo department, Colombia). July 2014-May 2015.

Vertical distribution of the psocid community: For the Mocoa locality, 85 males were collected during the sampling period, corresponding to 41 species, of which 40 were found in the canopy, with great abundance, representing $85.9 \%$ of the total of specimens collected in this locality. Only nine species were collected in the understory and Aaroniella sp. 3 was exclusive to this stratum. The other species were also found in the canopy, with a similar abundance, except for Cladiopsocus sp. 2, which was more abundant in the canopy $(\mathrm{N}=12)$ than in the understory $(\mathrm{N}=2)$. Specimens of the families Dolabellopsocidae, Epipsocidae, Lachesillidae and Myopsocidae, were exclusive to the canopy in this locality. The abundance of the species recorded in the understory was never higher than that in the canopy (Table 2).

At the locality of Puerto Asís, 267 males of 90 species were collected, of which 85 were present in the canopy, representing 89.1 $\%$ of the total of specimens collected. Only 22 species were recorded in the understory, and only Epipsocus sp. 23 and Dolabellopsocus sp. 2 were exclusive to this stratum. In the canopy, the most abundant genera were Epipsocus, Lachesilla, Psocidae, and Dolabellopsocus, representing $53.6 \%$ of the total (143 specimens); they were also the most represented genera in the understory, although with a marked difference in abundance in both strata, being the canopy always higher (Table 2, Table $3)$. In this locality was noticeable a large difference in the abundances of many of the species shared by the two strata; for instance, for the species of Epipsocus only eight specimens were found in the understory, and 47 specimens were found in the canopy.

The Kruskal-Wallis analysis of variance indicated that for the Mocoa locality (d.f. = $1, \mathrm{p}=0.2835$, chi-square $=1.1502)$ there were not significant statistical differences in the composition of the psocid community in both strata, but for Puerto Asís (d.f. $=1, \mathrm{p}=0.0011$, chi-square $=10.7250$ ) there were significant statistical differences for both strata. It can be observed graphically that, for both localities 
TABLE 3

Number of species of psocids (Richness) per genus, present in each locality and shared between the two localities of the Putumayo department, Colombia

\begin{tabular}{|c|c|c|c|c|}
\hline \multirow{2}{*}{ Genus } & \multicolumn{4}{|c|}{ Species richness } \\
\hline & Mocoa & Puerto Asís & Shared & Total \\
\hline Aaroniella & 2 & 2 & 0 & 4 \\
\hline Amazolachesilla & 0 & 1 & 0 & 1 \\
\hline Cladiopsocus & 4 & 3 & 0 & 7 \\
\hline Dolabellopsocus & 3 & 3 & 0 & 6 \\
\hline Epipsocus & 6 & 21 & 4 & 23 \\
\hline Euplocania & 1 & 5 & 0 & 6 \\
\hline Gojaoides & 1 & 2 & 0 & 3 \\
\hline Hemicaecilius & 0 & 1 & 0 & 1 \\
\hline Isthmopsocus & 1 & 4 & 1 & 4 \\
\hline Lachesilla & 2 & 16 & 0 & 18 \\
\hline Loneura & 0 & 2 & 0 & 2 \\
\hline Myopsocus & 2 & 4 & 1 & 5 \\
\hline Nadleria & 1 & 1 & 1 & 1 \\
\hline Neurostigma & 0 & 1 & 0 & 1 \\
\hline Peripsocus & 3 & 4 & 0 & 7 \\
\hline Perucania & 0 & 1 & 0 & 1 \\
\hline Psocidae & 17 & 24 & 5 & 36 \\
\hline Psococerastis & 0 & 1 & 0 & 1 \\
\hline Psocus & 0 & 1 & 0 & 1 \\
\hline Steleops & 0 & 3 & 0 & 3 \\
\hline Terryerwinia & 1 & 1 & 1 & 1 \\
\hline Trichadenotecnum & 3 & 3 & 1 & 5 \\
\hline Triplocania & 4 & 11 & 0 & 15 \\
\hline Total & 51 & 115 & 14 & 152 \\
\hline
\end{tabular}

the richness values in each stratum varied during the months sampled, being always the canopy values higher than the understory values (Fig. 4).

\section{DISCUSSION}

The data obtained in this work show the high level of underestimation on the characterization of the diversity in the Amazonian region, considered a hot spot of the world biodiversity, as well as the lack of knowledge of the psocid fauna, as genera and species were recorded, that were previously known in distant areas within the Amazon Basin, as the Rio Tambopata Reserved Zone in Peru, Mato Grosso and the Reserva Florestal Ducke in Brazil. Although it was far from reaching the maximum richness expected, according to the rarefaction curve for the localities and strata studied in this work, the number of species recorded in this small area, of less than $1 \%$ of the Colombian Amazonia (area of the Colombian Amazonia: $483164 \mathrm{~km}^{2}$; Murcia, Huertas, Rodríguez \& Castellanos, 2011), was more than $100 \%$ the number of described species for the country up to 2015. Being this work one of the first approaches to the knowledge of the psocid fauna of the Colombian Amazonia, it is not surprising to find that the species are unknown in the literature. For four of the nine families recorded, $80 \%$ of the species found had not been recorded in the literature, although there are important contributions on the diversity of the psocid fauna in the Peruvian, Ecuadorian and Brazilian Amazonian regions. 

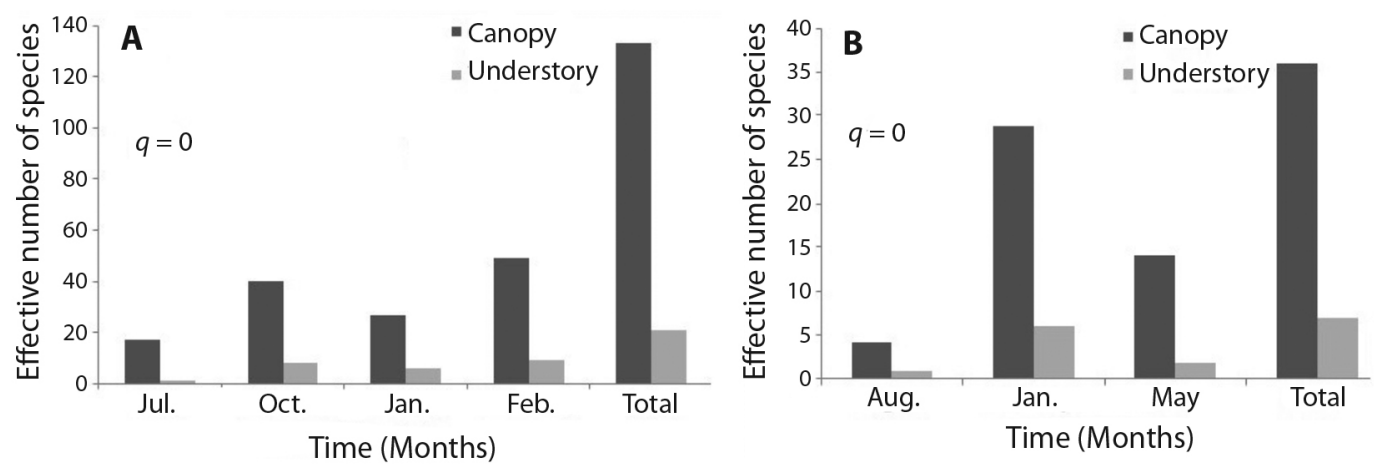

Fig. 4. Comparison of variation in species richness values $(q=0)$ for each of the strata (canopy and understory) in two localities of the Putumayo department, Colombia. A. Puerto Asis, B. Mocoa. Sampling period, July 2014-May 2015.

There is a well defined difference in the psocid diversity in the two localities studied, despite the small distance between them, both belonging in the same life zone (Bh-t). This agrees with previous findings of differences in diversity between localities in the Amazon Basin, where, in general, the number of species shared between localities, even if they are only a few meters apart, is quite small (Erwin, 1988; Louton, Garrison \& Flint, 1996; García Aldrete, 2008). It is important to notice some patterns in the distribution of the species richness and the abundance of psocid groups in these localities, such as the great abundance of Cladiopsocidae in Mocoa, a locality with little anthropic impact, the great richness and abundance of Epipsocidae and Lachesillidae in Puerto Asís, the great abundance of Psocidae in both localities, and the small number of species shared between them. The differences in diversity between the two localities might be consequence of their difference in altitudes, as psocid diversity is known to be negatively influenced by altitude (Turner, 1974; Turner \& Broadhead, 1974).

It is noteworthy the high psocid diversity in the highly agricultural locality of Puerto Asís, as the general tendency in various groups of insects in fragmented habitats is towards loss of diversity (Didham, Ghazoul, Stork, \& Davis, 1996); this tendency, however, had not been observed in psocid communities. It is also of interest that being the canopy the most diverse stratum, the area with less vegetation (Puerto Asís), has had the highest diversity values. The difference in altitude between the two localities does not allow a direct comparison, and little is known yet on barriers of dispersal for psocids, or if habitat fragmentation has an effect on psocid dispersal, as not always it has a negative effect on diversity (Quintana, Salomon, \& Lizarralde del Grosso, 2010).

The analysis of variance Kruskal-Wallis shows that for the locality of Mocoa, there are not significant differences in the psocid communities of the understory and the canopy, but the data show a highest richness in the canopy. Many singletons were found in this locality, which affects the median value, getting a value of 1 for both strata, so the difference in diversity between strata in Mocoa was given by the diference in richness and not by the abundance. For Puerto Asís, the results of the KruskalWallis test suggest a difference in richness and abundance in the two strata.

The results on vertical distribution for Mocoa and Puerto Asís agree with what has been found in studies with psocid communities conducted in the USA. Coots, Lambdin, Grand, Rhea and Mockford (2012) recorded a strong association of lachesillids with leaf litter, whereas in our study the lachesillids in the understory were $1 / 10$ of the total of specimens collected. The variation in the diversity of arthropods in the forest has been tried to be explained by the confluence of biotic 
and abiotic factors that, together with the forest architecture, modulate the presence or absence of the individuals. Blanc (1990) concludes that the microclimate in the canopy is rather different from that in the underlying vegetation, a fact that could promote the stratification of certain groups of arthropods in the forest. The evidence here presented supports the assertion that most of the diversity of tropical forests is found in the canopy (Basset, Cizek, Cuenoud, Didham, Guilhaumon et al., 2012). This stratification of the diversity, and the presence of individuals of the same species along the gradient canopy-understory, indicate how heterogeneous the life cycle of these individuals may be, as their distribution may be linked to the differential spatial distribution of the food sources, and the distribution of optimal places for oviposition, for the development of the immature stages, all influenced by physical factors as temperature, humidity and light exposure, variables that must be quantified, to assert their influence on the vertical distribution of the psocid communities.

It is important to mention the high efficiency of the LED light traps utilized, with which more than $90 \%$ of the specimens were collected, although a bias was observed in the data obtained, as a large proportion of the specimens collected were males. The methods utilized were highly effective to characterize the psocid diversity, although techniques like fogging could be complementary; New (1969, 2007) indicates that psocids are reluctant to fly, and the use of passive methods, as light traps, could underestimate the diversity in a given locality, so the combination of different collecting methods is recommended to characterize the psocid fauna, to avoid bias in the data obtained.

This study represents the first approach to know the psocid fauna of the Colombian Amazonia. The diversity found points to the need to explore the rest of the Colombian territory, as a high diversity and endemism is insinuated. With an increase in altitude, the psocid diversity decreases, besides, altitude seems to influence the exclusivity of some species.
There is a stratification of the psocid community studied, being the canopy the most diverse stratum, noting that the difference of diversity was kept throughout the period of sampling. It is suggested that, when conducting a survey of the psocid fauna in areas similar to the localities studied, the highest diversity will be found sampling the canopy. The use of LED light traps is an important alternative to sample the psocids in the canopy, complemented with the use of other sampling methods in the understory, for a better sampling of the total psocid fauna of a given place.

Ethical statement: authors declare that they all agree with this publication and made significant contributions; that there is no conflict of interest of any kind; and that we followed all pertinent ethical and legal procedures and requirements. All financial sources are fully and clearly stated in the acknowledgements section. A signed document has been filed in the journal archives.

\section{ACKNOWLEDGMENTS}

We are grateful to the inhabitants of the village Las Delicias (Puerto Asis) and the Environmental Center "Fin del Mundo" (Mocoa). To Nancy Carrejo for the elaboration of the map; to Juliana Hoyos for their help in field work. RGO thank Departamento de Biología, Facultad de Ciencias Naturales y Exactas, Universidad del Valle, Santiago de Cali, Colombia, for research support. ANGA thanks Instituto de Biología, Universidad Nacional Autónoma de México, for continuous research support.

\section{RESUMEN}

Diversidad y distribución vertical de psócidos (Psocodea: Psocoptera) en dos bosques de la Amazonía colombiana. Introducción: El conocimiento que se tiene acerca de la diversidad de psócidos en Colombia ha ido en aumento, siguiendo la tendencia mundial, pero el interés principal de la mayoría de estudios se ha centrado en la resolución de aspectos taxonómicos dejando de lado otros aspectos de su biología tales como las interacciones ecológicas de estos organismos en bosques tropicales. Objetivo: 
Describir la diversidad de psócidos en dos localidades de la Amazonía colombiana y proporcionar los primeros datos sobre su distribución vertical en bosques tropicales. Métodos: Se realizaron muestreos mensuales de psócidos durante los periodos de luna nueva entre julio 2014 y mayo 2015, en dos localidades del departamento de Putumayo, Colombia, utilizando trampas de luz LED. Resultados: Durante el periodo de muestreo, se recolectaron 152 especies, 23 géneros y nueve familias. La familia más rica en especies fue Psocidae, seguida por Epipsocidae y Lachesillidae. Más del $80 \%$ de las especies encontradas no están descritas y entre las descritas, nueve representan nuevos registros para Colombia y son compartidas con países vecinos de la cuenca del Amazonas. Catorce especies (9.2 $\%)$ son compartidas por las dos localidades de este estudio; Puerto Asís presentó mayores valores de diversidad que Mocoa. En ambas localidades se encontró una estratificación en la distribución vertical de Psocoptera, siendo el dosel el estrato más rico en especies. Conclusión: La relativamente alta diversidad de psócidos encontrada, así como el alto número de especies nuevas, es un indicador de la necesidad de continuar las exploraciones de estos organismos en el resto del territorio colombiano y países andinos, especialmente en el piedemonte amazónico. Fue evidente una estratificación de la comunidad de psocópteros estudiada, siendo el estrato dosel el más rico en especies, una tendencia que se mantiene a lo largo del año.

Palabras clave: dosel; sotobosque; ecología; estratificación; Putumayo.

\section{REFERENCES}

Basset, Y., Cizek, L., Cuenoud, P., Didham, R.P., Guilhaumon, F., Missa, O., Novotny, V.... \& Leponce, M. (2012). Arthropod Diversity in a Tropical Forest. Science, 338, 1481-1484.

Blanc, P. (1990). Bioclimatologie comparée de la canopée et du sous-bois. In F. Hallé \& P. Blanc (Eds), Biologie d'une canopée de forêt équatoriale (pp. 42-43). France: Rapport de Mission Radeau des Cimes Octobre-Novembre 1989, Petit Saut - Guyane Française Montpellier II et CNRS-Paris VI.

Calderón-Martínez, N.R., González-Obando, R. \& García Aldrete, A.N. (2014). Descriptions and records of Cladiopsocidae and Dolabellopsocidae (Insecta: Psocodea: 'Psocoptera') from Valle del Cauca and National Natural Park Gorgona, Colombia. Zootaxa, $3889,1-30$

Colwell, R.K. (2013). EstimateS 9.1. 0 User's Guide. University of Connecticut, Connecticut, U.S.A. Retrieved from http://viceroy.eeb.uconn.edu/EstimateS

Coots, C., Lambdin, P., Grand, J., Rhea, R., \& Mockford, E. (2012). Vertical stratification and co-occurrence patterns of the Psocoptera community associated with
Eastern Hemlock, Tsuga canadensis (L.) Carrière, in the Southern Appalachians. Forest, 3, 127-136.

Davis, A.J., Sutton, S.L., \& Brendell, M.J. (2011). Vertical distribution of beetles in a tropical rainforest in Sulawesi: the role of the canopy in contributing to biodiversity. Sepillok Bulletin, 13, 59-83.

Didham, R.K., Ghazoul, J., Stork, N.E., \& Davis, A. (1996). Insects in fragmented forests: a functional approach. Tree, 11(6), 1-7.

Erwin, T.L. (1988). The tropical forest canopy, the heart of biotic diversity. In E.O. Wilson (Ed.), Biodiversity (pp. 123-129). U.S.A.: National Academy Press.

García Aldrete, A.N. (1996). A new species of Nadleria (Psocoptera: Lachesillidae) from the Tambopata Reserved Zone, Madre de Dios, Peru. Entomological News, 107(1), 28-32.

García Aldrete, A.N. (1998). Description of the male Perucania longiareola New \& Thornton (Psocoptera, Ptiloneuridae). Acta Zoológica Mexicana, 74, 1-4.

García Aldrete, A.N. (2000). New South American Lachesilla in the group forcepeta (Psocoptera: Lachesillidae). Acta Zoológica Mexicana, 80, 69-99.

García Aldrete, A.N. (2005). Three new monotypic genera of Epipsocidae (Psocoptera) from Peru and Brazil. Zootaxa, 1077, 51-60.

García Aldrete, A.N. (2008). Lachesillidae (Insecta: Psocoptera) from the Tambopata Reserved Zone, Madre de Dios, Peru. Publicaciones Especiales del Instituto de Biología, 21. México D.F., México: Universidad Nacional Autónoma de México.

García Aldrete, A.N. (2010). Seven new species of Lachesilla (Psocodea: 'Psocoptera': Lachesillidae), in the group forcepeta from the Amazon basin. Acta Amazonica, 40(4), 749-756.

García Aldrete, A.N., \& Mockford, E.L. (2011). Amazolachesilla, a new genus of Eolachesillinae (Insecta: Psocodea: 'Psocoptera': Lachesillidae) from Amazonas, Brazil. Acta Amazonica, 41(4), 553-556.

García Aldrete, A.N., González, R., Carrejo, N.S., Mendivil, J.A., \& Calderón, N.R. (2013). Epipsocetae (Psocodea:'Psocoptera') from Valle del Cauca and NNP Gorgona, Colombia. Dugesiana, 20(2), 157-172.

García Aldrete, A.N., Carrejo, N.S., Mendivil, J., Calderón, N., Saenz, O., Panche, J... \& González Obando, R. (2018). Checklist of 'Psocoptera' (Psocodea) of Colombia and identification key to the families. Dugesiana, 25(2), 77-103.

González, R., Saldaña, C.L., \& García Aldrete, A.N. (2013). Lachesillidae (Psocodea: 'Psocoptera') de Valle del Cauca y PNN Gorgona, Colombia. Boletín 
del Museo de Entomología de la Universidad del Valle, 14(1), 51-69.

Gotelli, N.J., \& Colwell, R.K. (2011). Estimating Species Richness. In A. Magurran \& B. McGill (Eds.), Biological Diversity: Frontiers in Measurement and Assessment (pp. 39-54). United Kingdom: Oxford University Press.

Hammer, O., Harper, D.A.T., \& Ryan, P.D. (2015). PAST: Paleontological Statistics software package for education and data analysis. Oslo, Norway: University of Oslo.

Instituto de Hidrología, Meteorología y Estudios Ambientales. (2007). Mapa de ecosistemas continentales, costeros y marinos de Colombia. Retrieved from http://www.ideam.gov.co.

Jost, L. (2006). Entropy and diversity. Oikos, 113(2), 363-375.

Lienhard, C., \& Smithers, C.N. (2002). Psocoptera (Insecta). World Catalogue and Bibliography. Instrumenta Biodiversitatis $V$. Genéve, Switzerland: Muséum d'histoire naturelle.

Louton, J.A., Garrison, R.W., \& Flint, O.S. (1996). The Odonata of Parque Nacional Manu, Madre de Dios, Peru; Natural history, species richness and comparisons with other Peruvian sites. In D.E. Wilson \& A. Sandoval (Eds.), Manu. The biodiversity of southeastern Peru. (pp. 431-449). U.S.A.: Office of Biodiversity Programs. Smithsonian Institution.

Mockford, E.L. (2018). Biodiversity of Psocoptera. In R.G Foottit \& P.H. Adler (Eds.), Insect Biodiversity: Science and Society (Volume II, $1^{\text {st }}$ ed., pp. 417-456). United Kingdom: John Wiley and Sons.

Murcia, G.U.G., Huertas, M.C., Rodríguez, J.M., \& Castellanos, H.O. (2011). Monitoreo de los bosques y otras coberturas de la Amazonia colombiana, a escala 1:100.000. Cambios multitemporales en el período 2002 al 2007. Bogotá, Colombia: Instituto Amazónico de Investigaciones Científicas "Sinchi”.

New, T.R. (1969). Aerial dispersal of some British Psocoptera, as indicated by suction traps catches. Proceedings of the Royal Entomological Society of London. Series A, General Entomology, 44, 49-61.

New, T.R. (1980). Epipsocetae (Psocoptera) from the Reserva Ducke, Amazonas. Acta Amazonica, 10(1), 179-206.
New, T.R. (2007). Introducing Psocoptera. In T.R. New \& C. Lienhard (Eds.), The Psocoptera of Tropical South-east Asia (pp. 11-31). U.S.A.: Brill.

New, T.R., \& Thornton, I.W.B. (1975). Psocomorpha (Psocoptera) collected on recent expeditions to South America. Journal of Entomology Series B, Taxonomy, 44(1), 27-80.

New, T.R., \& Thornton, I.W.B. (1988). Epipsocetae (Psocoptera) from Peru. Studies on Neotropical Fauna and Environment, 23, 225-250.

Oksanen, J., Blanchet, F.G., Kindt, R., Legendre, P., Minchin, P.R., O'Hara, R., ... \& Wagner, H. (2013). Package 'Vegan'. Community Ecology Package, Version 2. Retrieved from http://CRAN.R-project.org/ package $=$ vegan

Quintana, M.G., Salomon, O.D., \& Lizarralde del Grosso, M.S. (2010). Distribution of Phlebotomine Sand Flies (Diptera: Psychodidae) in a Primary Forest-Crop Interface, Salta, Argentina. Journal of Medical Entomology, 47(6), 1003-1010.

R Core Team. (2013). R: A language and environment for statistical computing. R Foundation for Statistical Computing, Vienna, Austria. Retrieved from http:// www.R-project.org/

Silva Neto, A.M., Rafael, J.A., \& García Aldrete, A.N. (2014). New species of Triplocania Roesler, with forewing M3 forked (Psocodea: 'Psocoptera': Ptiloneuridae), from Brazil. Zootaxa, 3838(1), 77-86.

Smithers, C.N. (1990). Keys to the families and genera of Psocoptera (Arthropoda: Insecta). Technical Reports of the Australian Museum, 2, 1-82.

Thornton, I.W.B. (1981). The systematics, phylogeny and biogeography on the psocopteran family Philotarsidae. Systematic Entomology, 6, 413-452.

Turner, B.D. (1974). The population dynamics of tropical arboreal psocoptera (Insecta) on two species of conifers in the Blue Mountains, Jamaica. Journal of Animal Ecology, 43(2), 323-337.

Turner, B.D. (1975). The Psocoptera of Jamaica. Transactions of the Royal Entomological Society of London, 126(4), 533-609.

Turner, B.D., \& Broadhead, E. (1974). The diversity and distribution of psocid populations on Mangifera indi$c a$ L. in Jamaica and their relationship to altitude and micro-epiphyte diversity. Journal of Animal Ecology, 43(1), 173-190. 